\title{
A Produção do Espaço em Áreas de Auto-Segregação: O Caso da Barra daTijuca
}

\author{
Rosemere Santos Maia \\ Professora da Escola de Serviço Social/ UFRJ \\ Doutoranda em Geografia pelo PPGG/ UFRJ
}

\section{Introdução}

A Região Metropolitana do Rio de Janeiro tem sido marcada, ao longo dos anos, por um processo de crescimento que reflete, também espacialmente, “a coerência e as contradições dos sistemas econômico, institucional e ideológico prevalecentes no país”. (Abreu, 1987: 16).

Até a década de 70, de modo especial, era o Estado ${ }^{1}$ (aí compreendido nas suas diferentes instâncias de ação) que se constituía no principal agente de produção do espaço. Inserido na dinâmica da sociedade capitalista ( o que nos permite superar quaisquer tentativas de concebê-lo como neutro, “árbitro”), ele, não raramente, priorizou os interesses dos grupos dominantes econômica e politicamente, aprofundando as desigualdades sociais e acentuando, a exemplo do que nos sugere Abreu, as “disparidades intrametropolitanas, isto é, [a] crescente elitização dos espaços urbanos centrais e [a] conseqüente periferização das classes de baixa renda”. (1987: 15) Segundo Navet,

\footnotetext{
${ }^{1}$ Em relação ao papel preponderante do Estado no processo de produção do espaço, vale uma remissão a Lefebvre, (1978). A análise do autor situa-se a partir do II Pós-Guerra (chegando, aproximadamente, até a década de 70), época em que o Estado, ao centralizar o poder político, não só estende sua ação à regulação da economia e à estatização dos meios de produção, como, outrossim, torna-se o principal agente do processo de produção do espaço, fundando um Modo de Produção Estatal que, de um lado, controla fluxos (energia, matéria-prima, mão-de-obra, et.), e estoques (ou capital, investimentos, máquinas, técnicas, etc.) portanto o espaço e, de outro, introduz instrumentos e instituições de controle, regulação e gestão.
} 
Il existe donc une relation directe entre la constante stratification de l'espace et la mise en place de politiques publiques determinées. Si le modèle ségrégationniste de l'espace carioca est structuré principalement à parti des intérêts du capital et désidératas de la classe qui le représente, il a été légitimé et consolidé au fil des annés par l'Etat. (1989: 78)

Não é parca a bibliografia que analisa processos de segregação espacial na área metropolitana do Rio de Janeiro, sobretudo referindo-se a momentos em que o Estado, em nome da necessidade de "ordenar" o caos da cidade, acabou por aprofundar as diferenças na constituição e na vivência do espaço urbano: "cirurgias urbanas", remoção de favelas, construção de conjuntos residenciais nas periferias destinados à população pobre, restrita aplicação de recursos de infra-estrutura em áreas periféricas, dentre outros, são exemplos elucidativos desta situação.

A atuação deste agente - o Estado, embora preponderante, não pode ser vista como exclusiva, pois também foram fundamentais neste processo histórico de produção do espaço na cidade do Rio de Janeiro, tanto os representantes do capital (os grandes proprietários de terras, os incorporadores imobiliários, sem falar em outros segmentos da burguesia industrial e comercial), a classe média, instituições/organizações sociais- a Igreja, Movimentos Sociais (de favelas, bairros, minorias, etc.), ONG, dentre outras.

A produção de espaços “auto-segregados”, contudo, ainda não tem sido suficientemente analisada, apesar de, nos últimos 20 anos, ter adquirido uma enorme visibilidade em nossa cidade. Os poucos estudos existentes acabam ratificando o peso excessivo do Estado e dos Agentes do Capital, considerando muito pouco o papel de outros atores. Neste sentido, consideramos fundamental recolocar a discussão, apresentando as contradições e antagonismos presentes neste processo, bem como o nível e estratégias de intervenção dos diferentes agentes envolvidos.

\section{A Barra da Tijuca no Contexto Urbano do Rio de Janeiro:}

A Barra da Tijuca, uma área exemplar para a análise da produção de espaços auto-segregados, sofreu um boom de crescimento a partir de fins dos anos 60 e início da 
década de 70, época em que se verificou um intenso processo de especulação imobiliária, determinando a expansão da parte rica da cidade em direção a São Conrado e a esta região. Até a década de 60, não era nada além de uma área de difícil acesso, conhecendo, muito lentamente, uma ocupação ao longo de eixos de comunicação e de antigos caminhos rurais. Paulatinamente, foi se expandindo em direção ao norte (Tijuca) e ao longo do litoral, como um prolongamento das praias da zona sul. Era, sem dúvida, uma ocupação desordenada, com baixa densidade demográfica.

Nesta época, o governo do estado já começava a demonstrar preocupação com a planificação, objetivando garantir uma urbanização menos caótica da cidade. Em 63, o governador Carlos Lacerda solicitou a um arquiteto grego Doxiadis um plano para o Rio, plano este que pensava a Barra como um novo centro terciário e administrativo da cidade.(Navet, 1989:52). Segundo esta mesma autora:

Puis en raison de son potentiel naturel et face à la saturation des quartiers de la zone sud ainsi qu'à la croissance urbaine, la Barra suscitera des convoitises, le plan Doxiadis, Qui voyat dns la Barra le futur centre de Rio, n'a pas été appiqué mais son analyse d'une expansion de la métropole dans la direction de la Barra était retenue par la municipalité et les acteurs de la production capitaliste du logement à Rio.

Negrão de Lima (1968-1971), seguindo o exemplo de Lacerda, “encomendou” ao arquiteto Lúcio Costa um plano urbanístico para a Baixada de Jacarepaguá e para a Barra da Tijuca, objetivando estabelecer critérios para um desenvolvimento ordenado da área, de forma a evitar os problemas e os males que davam o tom a bairros como Copacabana, procurando conciliar expansão urbana com preservação da natureza.

A partir de então o Estado começa a ter aí ação decisiva na região, através de "investimentos maciços na construção de um complexo sistema viário (estradas, viadutos, túneis, elevados); implantação da infraestrutura urbana necessária para a ocupação da 'novíssima zona sul'; e, principalmente, regulação, mediante um plano urbanístico, desse processo de ocupação.”(Leitão, 1990: 9). Datam, desta época, construções como da Avenida Litorânea (atual Sernambetiba) Grajaú-Jacarepaguá e Avenida das Américas.

Constata-se, assim, que o Estado num momento em que também se evidenciava a expansão urbana na Baixada Fluminense, sob bases bastante diferenciadas ${ }^{2}$ - voltava sua atenção e seus investimentos para a Barra, vislumbrada como passível de ser

\footnotetext{
${ }^{2}$ Naquele momento, não havia, ainda, se processado a fusão entre Rio de Janeiro e Guanabara e a Região Metropolitana (ainda que não constituída legalmente) já apresentava distorções, demonstrando um processo de diferenciação de investimentos e recursos, quanto mais afastado do núcleo (no caso a Guanabara) o Município estivesse.
} 
integrada, no futuro, ao núcleo metropolitano, dada sua tendência de ocupação por classes de alta renda. (Abreu, 1987: 18)

Cabe contextualizar, ainda que brevemente, o momento em que este plano foi elaborado os "anos do milagre”: época em que houve um aumento substantivo do PIB, da exportação e do consumo de bens duráveis, sem falar na produção imobiliária (financiada pelo BNH) e um investimento acentuado do Estado em políticas urbanas que privilegiavam os segmentos mais abastados.

\subsection{O Plano Lúcio Costa.}

Num contexto em que não era comum a realização de planos diretores de urbanização, e diante da preocupação do Governo do Estado da Guanabara com a garantia da ocupação ordenada da Barra considerada fundamental para o processo de expansão da cidade e constituição de um novo núcleo metropolitano confiar a Lúcio Costa tal tarefa foi, em certa medida, depositar em seu nome mais que o crédito na sua competência; na verdade, foi uma tentativa de garantir a aceitação coletiva do plano. Esta aceitação seria fundamental, sobretudo em se tratando do fato de que o plano se voltava ao ordenamento / urbanização de uma área não pertencente ao Estado. Desta forma, os primeiros a serem convencidos de sua pertinência e viabilidade deveriam ser os efetivos proprietários dos loteamentos.

O princípio básico do plano era a nuclearização das zonas residenciais coletivas, resguardando-se, ainda, espaços intermediários para uso unifamiliar. Na orla, contudo, limitavam-se construções altas ao uso residencial multifamiliar.

Segundo o plano piloto, a região abrangida contaria com três centros urbanos principais: “o primeiro na Barra, junto ao Jardim Oceânico; outro em Sernambetiba, contíguo ao Recreio dos Bandeirantes; e o terceiro eqüidistante dos dois citados, que se transformaria no 'futuro grande centro metropolitano NS-LO’” (Leitão, 1990: 89). Nestes, algumas atividades seriam desenvolvidas: comércio, lazer, cultura, escritórios.

Dada a vocação para o turismo que se vislumbrava para o local, previa-se ainda a construção de hotéis, mas em áreas previamente definidas. A Avenida Litorânea (hoje Sernambetiba) deveria manter-se rústica, de forma a integrar-se ao ambiente que se pretendia preservar: nada de mão-dupla, canteiro central, retorno. 
Seria necessária a complexificação do sistema viário, de forma que fosse facilitada a ligação entre o Centro Metropolitano projetado com outros bairros e, sobretudo, com o Centro da Cidade: além de rodovias, Lúcio Costa também previra o metrô.

Haveria, ainda, uma área destinada ao uso industrial, de fácil acesso aos subúrbios e à trama rodoviária do Estado, área esta que já era ocupada por segmentos oriundos da classe trabalhadora. Ficaria situada entre a Colônia Juliano Moreira e as estradas do Capão e do Engenho d’Água (logo, bem distante da orla).

Fica claro que o plano piloto excluía da Barra os segmentos pobres, incentivando sua instalação em espaços declaradamente segregadores.

Segundo este plano, também, a rua deixaria de ser um espaço de convivência e sociabilidade, passando a cumprir a função exclusiva de canal de circulação.

A nuclearização das zonas residenciais acabava por inibir o movimento na cidade. Os condomínios exclusivos- símbolo da Barra- acabariam se tornando uma “cidade dentro da cidade”, onde seriam assegurados aos seus moradores "uma estrutura de comércio local bastante desenvolvida, as mais diversas formas de lazer e, até mesmo, um sistema de transporte coletivo próprio, ligando o condomínio com outros pontos da cidade. (Leitão:1990: 121)

O plano elaborado por Lúcio Costa acabou por sofrer, ao longo das décadas que se sucederam, uma série de alterações, fruto da pressão de segmentos os mais variados, que apontavam para suas incongruências e anacronismos.

Uma das mudanças mais simples refere-se à não-aceitação da orientação do plano no que se refere às redes de energia que, sob qualquer hipótese, deveriam ser aéreas. Em razão dos custos das redes subterrâneas que não poderiam ser arcados pelo poder público, acabou-se adotando a alternativa mais barata, porém menos estética.

Outras alterações, contudo, mexeram de forma mais essencial nas concepções do arquiteto. 
Em relação à ampliação do sistema viário, que facilitaria a acessibilidade (dentro de um esquema metro-rodoferroviário), houve um adiamento de sua implementação, igualmente por falta de recursos, bem como não se mostraram eficazes as alternativas apresentadas ao equacionamento da questão de saneamento da região, resultando em conflitos, sobretudo durante a década de 80, entre Estado e organizações da sociedade civil - como a AMABARRA, grupos ecológicos, etc. (Evangelista, 1989: 63)

Houve, ainda, inúmeras alterações no que concerne ao parcelamento da terra, ao uso do solo e ao tipo de edificação, fruto de intervenções, num primeiro momento, da administração estadual e, após a fusão, da administração municipal, não raras vezes pressionadas pelos empresários do setor imobiliário que tentavam ajustar o plano aos seus interesses.

Deu-se um aumento do gabarito da orla marítima, permitindo-se a construção de edifícios de cinco pavimentos mais cobertura (no plano original, a previsão era de apenas dois), possibilitando um maior aproveitamento da área construída.

\subsection{O Decreto 3.046/81 e a “consolidação” das alterações no Plano Lúcio Costa:}

Em abril de 1981, baixou-se o Decreto 3.046 que consolidava alterações no Plano Piloto de Lúcio Costa, passando a reger a ocupação da Barra e da Baixada de Jacarepaguá. Este decreto foi fruto de reflexões de um grupo de trabalho, instituído pelo então prefeito Júlio Coutinho. A princípio, contou com a participação de conservacionistas, representantes de entidades de classes e comunitárias, paisagistas e empresários. Em função de dissensos internos e a partir da constatação de que os interesses do setor empresarial vinham tendo hegemonia, os conservacionistas, paisagistas e representantes comunitários abandonaram o grupo, ficando, enfim, a cargo da Secretaria Municipal de Planejamento e do setor empresarial o detalhamento da lei.

Com o decreto, uma nova legislação urbanística estava criada para a Barra e Baixada de Jacarepaguá, alterando gabaritos, criando novas condições de parcelamento e autorizando a construção de hotéis-residências ao longo da orla. Estas alterações propostas passaram a mexer essencialmente no perfil da região, produzindo uma verticalização acentuada e uma diversificação de usos do espaço, sobretudo em se tratando da Avenida Sernambetiba. 
Em 1986, a Prefeitura propôs a realização do Seminário “Barra 86- avaliação e perspectivas para o desenvolvimento”, tendo como objetivo

Avaliar o papel desempenhado pelo Plano Piloto como instrumento ordenador da ocupação da Barra da Tijuca e Baixada de Jacarepaguá, analisar os efeitos das principais alterações sofridas pelo plano desde a sua criação e discutir novas propostas de desenvolvimento urbano para essa região. (Leitão: 1990: 165)

Neste seminário, que contou com a participação de vários órgãos da administração municipal e estadual, bem como de representantes da Sociedade Civil ADEMI (Associação de Dirigentes de Empresas do Mercado Imobiliário), Instituto de Arquitetos do Brasil, Sindicato da Indústria da Construção Civil, (e Associações de Moradores), foi consensual a avaliação do Plano Lúcio Costa enquanto instrumento que conseguiu conter a ocupação indiscriminada da Barra. Constatou-se, porém, a necessidade de constante revisão da legislação urbanística, tendo em vista o caráter histórico da sociedade. Além disto, foram explicitadas as principais dificuldades de assentamento dos equipamentos de infra-estrutura urbana.

Os participantes do Seminário, subdivididos em comissões específicas, apresentaram, ainda, algumas propostas, como a redefinição de áreas do Plano Piloto para ocupação pela população de baixa renda, de modo a facilitar a vida daqueles que trabalhavam na Barra; a urbanização e regularização das favelas que não se encontravam em áreas de risco e remanejamento da população estabelecida em locais arriscados; a reavaliação dos padrões de parcelamento, das tipologias das edificações e de seus usos, de modo que pequenos e médios empresários pudessem participar do processo de expansão urbana; a criação, pelo Poder Público Municipal, de canais de participação para a comunidade local, de forma que seus representantes pudessem intervir no processo de estruturação urbana. Dada a vocação para o turismo apresentada pela Barra, propôsse, também, a criação de áreas de lazer, hotéis de 2 e 3 estrelas, campings, hotéis de lazer, etc, isto sem falar na preocupação demonstrada em relação à resolução da questão de saneamento básico da região. 
Sem dúvida, algumas destas propostas acabaram soando junto aos representantes do grande capital imobiliário como uma ameaça, como um indício de que seu poder de influência junto ao Estado, bem como sua hegemonia na definição dos rumos do processo de produção do espaço na área analisada encontravam-se postos em xeque. Insatisfeitos, articularam-se e propuseram a realização de um plebiscito (1988) com vistas a referendar a emancipação da Barra em relação ao Município do Rio de Janeiro. Segundo Leitão:

Os grupos que defendem a emancipação pretendem, através do controle político da administração do futuro município, assegurar (e ampliar) a permanência de um quadro que fez da Barra "o Eldorado urbano" do grande capital imobiliário. Para alcançar esta meta, elaboram uma estratégia que lhes permita, um uma nova conjuntura política, a "captura" legitimada pela realização de um plebiscito, de uma das instâncias da administração pública- a municipal -, fazendo com que esta passe a atuar de acordo com os interesses desse segmento do capital imobiliário, no que se refere à modelagem do espaço urbano. (...) A criação do novo município é apresentada, dessa maneira, como a única solução para os problemas decorrentes da redução dos investimentos públicos na conservação e ampliação da infra-estrutura urbana na área do Plano. (Leitão, 1990 : 189)

Bandeiras pró e contra esta proposta foram levantadas, articulando e medindo forças entre segmentos os mais variados e culminando na derrota da proposta.

\section{$3 \mathrm{O}$ atual processo de expansão da Barra - impasses e perspectivas: ${ }^{3}$}

Os fins dos anos 80 e toda a década em curso vêm demonstrando que os impasses presentes no processo de urbanização da Barra da Tijuca estão longe de ser

\footnotetext{
${ }^{3}$ Embora não tendo sido a tônica do presente trabalho, consideramos pertinente apresentar, em anexo, alguns quadros que nos informam sobre alguns indicadores sócio-econômicos dos diferentes bairros do Rio de Janeiro, dentre os quais gostaríamos de destacar a Barra da Tijuca que no contexto das APs, situa-se na região 5 (Comportamento da População nas APS, de 1960 a 2000- fonte IBGE)-; e, na classificação de Marques(1993) é inserida no grupo "Espaço das Classes Altas".
} 
resolvidos. Ao contrário, o recrudescimento da ocupação da Barra vem, dia-a-dia, pondo a nu as contradições relacionadas à gestão do local. Cada vez mais, a região contrapõe-se ao protótipo vislumbrado, em fins dos anos 60, por Lúcio Costa.

A abertura à descaracterização que foi “permitida” pelo Decreto 3.046/81, e outras leis complementares, sem falar no crescente processo de favelização e ocupação de áreas irregulares, só vem a demonstrar que a produção do espaço não pode ser pensada tão somente a partir de sua dimensão material, dada sua essência política. O Grande Capital de Incorporação parece dominar na área, construindo condomínios e shopping centers. O Estado, ainda que com maior "moderação" que em décadas passadas, continua investindo vultuosas quantias em obras de urbanização- só em termos de rodovias, podemos mencionar a duplicação da Avenida das Américas, Ayrton Senna, Sernambetiba, sem falar na recente construção da Linha Amarela, ligando a Barra a Zona Norte.

Em relação às obras supramencionadas, valem algumas considerações:

- A urbanização da Sernambetiba fere, mortalmente, o disposto no plano piloto pensado por Lúcio Costa. Sua duplicação, seus calçadões e traillers a tornam muito mais próxima do que, em fins dos anos 60 se queria evitar (a Barra como uma nova Copacabana) que de uma estrada rústica, integrada à paisagem natural proposta pelo urbanista.

- A Avenida das Américas, embora iniciando na Barra e ultrapassando a Grota Funda, seguindo em direção a outros bairros da Zona Oeste (Guaratiba, Campo Grande, Santa Cruz) só mereceu devida "atenção" do governo até o limite com o Recreio, demonstrando o forte conteúdo segregativo de suas iniciativas.

A construção da Linha Amarela foi marcada por traumas junto à população pobre que ocupava áreas cortadas pela rodovia, que teve que ser removida e reassentada (cerca de 10.000 moradores, segundo dados do CEAP- Centro de Educação Ambiental e Popular- ONG que atuou junto a esta população no sentido de discutir "todos os problemas inerentes à obra e suas possíveis soluções, o destino das áreas remanescentes, além de orientações sobre legislação e direitos do cidadão"). Uma outra questão a ser mencionada é que esta obra, ao tentar encurtar distância entre dois lados da cidade (sem dúvida, marcados por visíveis contrastes) acabou por dividir os moradores da Barra, um grande número deles sentindo-se "invadidos em seu território" em razão de tal obra ter, para além de facilitar seu deslocamento pela cidade, favorecido o acesso de "suburbanos" às praias da região e distendendo a tão desejada assepsia por parte dos grupos privilegiados. 
A Barra vem, cada vez mais, tentando afirmar sua face exclusivista, com a ampliação do número de condomínios e shopping centers e, mais recentemente, de centros empresariais. Parece que a "profecia” de que o bairro poderia vir a se constituir num novo núcleo urbano começa a se concretizar. Empresários, profissionais liberais moradores ou não do local vêm investindo em negócios na região, o que atrai consumidores e usuários de serviços os mais diversos de várias partes da cidade, demandando, também, mão de obra para levar estes negócios a termo.

Os grandes shopping centers (como o Barra Shopping, o maior da América Latina), para além de templos de consumo, tornaram-se referências de lazer e outros serviços para a população em geral, embora entre os moradores da Barra, sejam vistos como a extensão de seus condomínios.

A vivência condominial, agora também desejada por setores menos privilegiados da população do Rio de Janeiro (classe média baixa, sobretudo) suscita uma prática curiosa: empreendedores imobiliários, ancorados neste anseio pela exclusividade observado entre este segmento, vêm construindo condomínios de menor custo em áreas situadas na periferia da Barra, ou mesmo na Baixada de Jacarepaguá, anunciando-os, contudo, como que localizados naquele Bairro. Ainda que, objetivamente, os limites entre os bairros estejam bem demarcados, a nível do imaginário poderíamos supor que está em processo de construção uma “Nova Barra”- extensão, talvez, do que, um dia, alguém ousou chamar de "Eldorado Urbano”.

Malgrado toda a importância que o planejamento urbano teve no processo de ocupação da Barra da Tijuca, articulando ou contrapondo diferentes agentes na luta pela hegemonia no que concerne à definição do destino do bairro, é de fato bastante estranho que, no momento em que nos encontramos, o debate não tenha se mantido tão efervescente.

A Constituição de 1988, fruto da mobilização da sociedade civil num período de distensão do regime ditatorial, coloca algumas possibilidades para a discussão acerca do planejamento urbano que, em fins dos anos 70 e por toda a década de 80, os agentes que, direta ou indiretamente, intervieram no processo de desenvolvimento da Barra reclamaram ou contestaram.

Os diferentes segmentos que estiveram à frente deste processo de mobilização, especificamente no que se refere à discussão sobre a Reforma Urbana, requeriam um 
novo padrão de planejamento urbano capaz de, antes de mais nada, compreender o espaço urbano como "uma arena onde se defrontam interesses diferenciados em luta pela apropriação de benefícios em termos de rendas e ganhos gerados pela ocupação do solo da cidade, por um lado, e em termos de melhores condições materiais e simbólicas de vida, por outro.” (Ribeiro e Santos Junior, 1993: 55) Neste sentido, ele deveria, segundo os autores, "gerar intervenções que promovam a melhoria das condições urbanas de vida, sobretudo para o conjunto dos trabalhadores".

Visava-se, com este entendimento, superar as visões tecnocráticas que foram hegemônicas na década de 70 e que, na verdade, constituíam-se num "conjunto de planos, instrumentos e legislações que tem a cidade e os cidadãos como objetos, e não como sujeitos da política (...) planejamento como instrumento estatal de ação sobre a cidade.” (Egler, 1994: 77)

Constatado o fracasso do que se supunha como um Estado de Bem Estar Social, o planejamento que se requeria era aquele que pudesse valorizar "a descentralização das estruturas de gestão, a diversidade dos instrumentos de planejamento e ação dos agentes sociais”. (Harvey: 1993; apud Egler, 1994: 75) Isto porque ele (o Estado) mais e mais tornara-se incapaz de "investir, construir e gerir a totalidade dos processos espaciais, abrindo frente para a participação dos agentes econômicos e sociais”. (Egler, 1994: 79). Contudo, segundo Egler,

Paradoxalmente, a Constituição de 1988 resgata o plano diretor como estruturante da política urbana no país. Ao obrigar a realização de planos diretores em municípios com mais de 20.000 habitantes, a nossa Constituição reafirma o ideário totalizador do planejamento urbano da cidade moderna. (1994: 76)

A Constituição do Estado do Rio de Janeiro, como não poderia ser diferente, não apresentou questões e deliberações que viessem a se contrapor ao que fora deliberado pela Carta Magna. Contudo, avançou no que pode, tendo em vista as lacunas apresentadas por ela e que foram, sabida e estrategicamente, potencializadas pelos setores progressistas que participaram do processo de sua elaboração. Segundo Gonçalo (1997), 
Em linhas gerais podemos dizer que o Capítulo Da Política Urbana representou um avanço no sentido de recuperar a cidade, ao situar a função social da cidade ${ }^{4}$ acima do direito de propriedade, reforçar a participação popular e responsabilizar o município na gestão do seu território. Houve um avanço, também, quanto aos instrumentos de controle do uso do solo urbano, ao priorizar as camadas menos favorecidas da sociedade no uso das terras públicas.

Afinada com as orientações da Constituição Federal, a Estadual mantém o dispositivo referente à criação de planos diretores para cidades com mais de 20.000 habitantes.

O Plano Diretor Decenal da Cidade do Rio de Janeiro, aprovado em 1993, mantém-se, em certa medida, aprisionado aos padrões tecnocráticos e normativos característicos da década de 70, sendo, a exemplo do que sugere Egler, ”proposições de natureza geral que incidem sobre a totalidade da cidade.” (1994: 79) Em se tratando da questão referente à intervenção sobre o urbano, pode-se constatar uma setorialização das medidas (uso do solo, habitação, transportes, equipamentos coletivos), pautandose, ainda, no princípio do zoneamento.

Tendo um tom universalizante e pretensamente democrático, o plano diretor pretende-se enquanto um instrumento de busca da eqüidade e da justiça social, passíveis de serem concretizadas a partir da "criação de condições de acesso à terra, à habitação, ao trabalho, aos transportes e aos equipamentos urbanos” ao conjunto da população, sem falar no seu estímulo à participação “no planejamento urbano e na fiscalização”, "reforçando o sentimento de cidadania e proporcionando o reencontro do habitante com a cidade.” (Prefeitura do Rio de Janeiro, 1993: 15)

O Plano Diretor Decenal da Cidade do Rio de Janeiro tenta, outrossim, encarar o problema referente ao preço da terra urbana. Para tal, vem propondo a aplicação

\footnotetext{
4 "As funções sociais da cidade são compreendidas como o direito de todo cidadão de acesso à moradia, transporte público, saneamento básico, energia elétrica, gás canalizado abastecimento, iluminação pública, saúde, educação, cultura, creche, lazer, água potável, coleta de lixo, drenagem de vias de circulação, contenção de encostas, segurança, preservação do patrimônio ambiental e cultural.” (Guimarães, 1997)
} 
de dispositivos como o solo criado e o imposto territorial progressivo no tempo, de modo a, associados a outros mecanismos tradicionais,

provocar, a mais curto prazo, mudanças no mercado imobiliário urbano que contribuam para diminuir o déficit habitacional existente, seja redirecionando o mercado para outras regiões da cidade, seja gerando recursos para aplicação em infra-estrutura e programas habitacionais. (Cavallieri e Bezerra: 1996, 243)

No que se refere à Área de Planejamento 4, que inclui a Barra da Tijuca e a Baixada de Jacarepaguá, constatamos que, em relação à primeira há toda uma preocupação com o sistema viário, o que demonstra que a acessibilidade é, ainda, um dos pontos nevrálgicos da região. Verifica-se, igualmente, uma atenção especial com o meio ambiente (preservação, pesquisa, educação ambiental), bem como com o turismo, a cultura e o lazer- há muito vistos como vocação da região.

Já no que tange a Jacarepaguá, notam-se diretrizes que demonstram um esforço de melhor definir regras de sua ocupação, evitando desordenamento, além de proposta de medidas que fixem os moradores/ trabalhadores na região ${ }^{5}$. Parece que, ao explicitar questões como estas ao tratar da área da Baixada de Jacarepaguá e, em contrapartida, omiti-la, ao se referir à Barra, o plano diretor não supera, efetivamente, o conteúdo segregativo dos planos que o antecederam. Se os segmentos pobres quiserem se instalar na região, que procurem e se mantenham no lado do "primo pobre". Com isto, desconsidera-se, por exemplo, o fato de que, na própria Barra, há áreas favelizadas e/ou em processo de favelização, situadas em locais de risco, que só têm merecido atenção dos governantes em momentos de enchentes (onde os desabrigados são deslocados para assentamentos em Jacarepaguá).

Embora contenha as "normas gerais" para ordenamento do crescimento da cidade, o Plano Diretor aponta a necessidade de criação de 55 PEUs ( Projetos de Estruturação Urbana), com participação popular, cuja incumbência será o detalhamento

\footnotetext{
${ }^{5}$ Art. 69- As diretrizes de uso e ocupação do solo para a Área de Planejamento 4 são as seguintes: (...)

II-incentivo à localização de atividades geradoras de emprego, para redução de deslocamentos, mediante o fortalecimento do centro de comércio e serviços Taquara-Tanque;(...)

XI-consolidação das áreas destinadas à ocupação industrial, inclusive dos pólos de desenvolvimento industrial.(...)

XVI-Contenção do processo de ocupação desordenada da Baixada de Jacarepaguá, especialmente nas áreas lindeiras às lagoas, canais e outros cursos d’água.
} 
destas normas, a partir das especificidades/ peculiaridades apresentadas pelas UEPs (Unidades Especiais de Planejamento), compostas por cada bairro ou conjunto de bairro que as compõem. Com isto, o Plano Diretor pretende resgatar a valorização do lugar, ”suas interações sociais e territoriais.” (Egler:1994: 80-1)

É, no mínimo, curioso que, malgrado as possibilidades postas a partir de 1988 (pelas Constituições Federal e Estadual, Plano Diretor da Cidade), a Barra mantenha-se, conforme declarações de técnicos tanto da SMU, quanto da Subprefeitura , ainda orientada ( ou “des-orientada”) pelo Decreto 3.046/81. Quando indagados sobre a existência, ao menos, do debate em relação à proposição do PEU para a região foram unânimes em afirmar que não se tinha qualquer iniciativa a este respeito ( e isto há cinco anos de vigência do plano decenal). Seria este um indício de que, nas duas décadas anteriores a maior mobilização evidenciada na Barra partira, mesmo, do setor empresarial e, agora, satisfeitos com os rumos que ajudaram a traçar para a região, consolidados na Lei 3.046/ 81, não mais estariam preocupados em participar do debate? E a AMABARRA? Qual fora, efetivamente, seu papel na produção do espaço? Suas reivindicações teriam sido apenas pontuais, sem grande conteúdo político e, diante da resolução ( ou minimização) das questões em razão das quais seus membros se articularam, aquela organização estaria desfeita? E outras organizações da sociedade civil- por que não estariam se envolvendo com a questão?

Com certeza, a resposta a estas indagações poderia nos indicar importantes elementos para a compreensão do processo de urbanização pelo qual vem a Barra passando, sem falar na projeção de seus rumos. Contudo, gostaríamos de assinalar que, aprofundar esta discussão demandaria um outro nível de envolvimento investigativo que não teríamos, no momento, condições de empreender.

Gostaríamos de sugerir, contudo - e esperamos que nossa proposição não seja tomada como leviana que parece implícita na ação de alguns setores do Estado, do empresariado e da sociedade civil que atuam no processo de produção do espaço na Barra da Tijuca uma tendência a “não mexer no time que está ganhando”- e, aí, incluemse os interesses destes segmentos, em detrimento daqueles referentes aos setores menos privilegiados que, ao que tudo indica, encontram-se longe de acessar a condição de cidadania na referida área. A eles, continuariam reservados locais segregados, de preferência longe da orla e dos condomínios de luxo ou, quando muito, os elevadores de 
serviço e as atividades sem qualificação e/ou domésticas demandadas pela parcela privilegiada. Agindo desta forma, aqueles segmentos deixariam clara a crença na assepsia da exclusividade, pautada num repertório infindo de preconceitos.

\section{Os principais agentes envolvidos na produção do espaço na Barra da Tijuca.}

Parece-nos claro, a partir de toda a discussão que vimos empreendendo, que a disputa que se dá no contexto citadino pelo uso do solo decorre da concentração de pessoas, grupos, classes e organizações que, em razão das diferentes atividades que realizam e necessidades que possuem, tentam garantir a prerrogativa de intervir no processo de produção do espaço e usufruto do mesmo. Segundo Singer,

esta disputa se pauta pelas regras do jogo capitalista, que se fundamenta na propriedade privada do solo, a qual por isso e só por isso proporciona renda e, em conseqüência, é assemelhada ao capital. A posse de meios de produção é condição necessária e suficiente para a exploração do trabalho produtivo, ao passo que a ocupação do solo é apenas uma contingência que o seu estatuto de propriedade privada torna fonte de renda para quem o detém. (1982:21)

No processo de urbanização da Barra da Tijuca, vários atores, como temos tentado demonstrar até agora, têm estado presente, desempenhando diferentes papéis, interferindo em maior ou menor grau no perfil que o referido bairro (bem como aqueles que o circundam) vêm assumindo no contexto da Cidade do Rio de Janeiro. Já introduzimos alguns elementos necessários à análise do papel do Estado neste processo, bem como outros referentes ao "capital imobiliário". Contudo, tendo em vista propor uma melhor sistematização da discussão, o que consideramos necessário para a introdução de outros agentes, tentaremos objetivar o nível de "intervenção" de cada um deles, bem como suas possíveis alianças e articulações.

\subsection{O Estado.}

Sua importância como agente produtor do espaço urbano é inegável, mesmo num momento em que, por força do avanço do projeto neoliberal e do processo de 
globalização (que, para alguns autores, poderia ser um indício da dissolução do EstadoNação, o que é extremamente questionável) ${ }^{6}$, ele tem empreendido esforços no sentido de minimizar suas funções. Malgrado este fato, é ele quem, nestes tempos "pósmodernos”, ainda atua de maneira decisiva como agente modelador do espaço urbano. Falando sobre o nível de intervenção estatal neste processo, Leitão afirma que sua atuação se dá:

Promovendo o desenvolvimento de diferentes formas e usos mediante a taxação diferenciada dos imóveis urbanos e, conseqüentemente, estimulando (ou não) a especulação imobiliária, pelo fornecimento de crédito que vai possibilitar o acesso à moradia das demandas não solventes, mobilizando reservas fundiárias públicas e colocando, dessa forma, no mercado áreas até então estocadas; elaborando a legislação urbanística (ou planos diretores específicos para determinadas áreas) que vai orientar o processo de expansão urbana; e por intervenções diretas, com a "produção do chão", que ocorre através de drenagens, aterros e desmonte de morros, permitindo a apropriação de terrenos não utilizados. (1990: 57-58)

O Estado, no processo de produção do espaço urbano, possui uma atuação muito mais complexa que a de muitos outros agentes. Isto porque não fica imune às contradições emanadas da sociedade e, por isto mesmo, confronta-se sempre com o dilema de ter que respondê-las (de forma diferenciada, é bem verdade, como já sugerimos anteriormente), sob pena de não conseguir se legitimar.

No caso da urbanização da Barra da Tijuca, não fosse a intervenção estatal no sentido de prover a infra-estrutura básica, contribuindo para a habitabilidade e a acessibilidade, sem falar na diferenciação da tributação em relação a outras áreas mais afastadas do núcleo da cidade, com certeza o bairro não teria alcançado o padrão de crescimento que tem hoje, tampouco apareceria no imaginário de muitos grupos/ segmentos sociais como "sonho de consumo", local capaz de congregar todos os adjetivos necessários ao "bem viver”.

\footnotetext{
${ }^{6}$ Becker (1988) reconhece “a crise do Estado e a tendência à sua fragmentação política e espacial", mas não chega a postular seu fim, reconhecendo que "tensões entre novos atores econômicos e sociais com lógicas próprias, ao lado de práticas políticas convencionais, uma tendência atomizante com enclaves de articulação, configuram o complexo Estado contemporâneo”.
} 
Como já foi mencionado, o Estado seria, então, o principal agente do processo de segregação espacial observado nas cidades, a medida em que sua intervenção em áreas destinadas aos setores menos privilegiadas dá-se com menos ênfase, sendo ampliada em momentos estratégicos (como em época de eleições) e não raras vezes utilizada como forma de clientelismo político, apresentando-se como "boa ação".

Singer, contudo, critica a forma como o Estado é colocado como o algoz deste processo, afirmando:

Quem estuda um mapa da distribuição dos serviços urbanos de responsabilidade do Estado no território da cidade verifica facilmente que eles se encontram apenas à disposição dos moradores de rendimentos elevados ou médios. Quanto menor a renda da população, tanto mais escassos são os referidos serviços. Isto poderia despertar a suspeita de que o Estado agrava sistematicamente os desníveis econômicos e sociais, ao dotar somente parcelas da população que já são privilegiadas de serviços urbanos, dos quais as parcelas mais pobres possivelmente carecem mais. Mas a suspeita é infundada. Quem promove esta distribuição perversa dos serviços urbanos não é o Estado, mas o mercado imobiliário.

Sendo o montante de serviços urbanos escassos em relação às necessidades da população, o mercado os leiloa mediante a valorização diferencial do uso do solo, de modo que mesmo serviços fornecidos gratuitamente pelo Estado aos moradores - como ruas asfaltadas, galerias pluviais, iluminação pública, coleta de lixo, etc.- acabam sendo usufruídos apenas por aqueles que podem pagar o seu preço incluído na renda do solo que dá acesso a eles. (1982: 35-6)

Parece-nos uma visão simplista esta defendida por Singer, caracterizando-se, talvez, como uma inversão do processo, onde, como já foi indicado, estes elementos por ele citados, em termos infraestruturais, são de suma importância no processo de valorização do solo urbano, sem falar em outras medidas empreendidas pelo Estado, como desfavelização, periferização dos segmentos pobres, que acabam por contribuir neste sentido. As diferentes "reformas" ocorridas na Cidade, desde Pereira Passos, servem bem para ilustrar a questão. 


\subsection{O capital de incorporação:}

Os agentes incorporadores, no processo de produção do espaço urbano, apresentam uma extrema flexibilidade em suas ações, sempre abertos às inovações. Como não poderia deixar de ser, contudo, esta abertura se dá desde que não fira seus interesses econômicos. Concentrando seus investimentos em áreas nobres, ou mesmo populares, mas em processo de ocupação por setores privilegiados, lá costumam atuar até quando, a exemplo do que nos demonstram Ribeiro e Azevedo, “ ocorre o início de saturação destas áreas, com o conseqüente encarecimento da terra, produz-se o deslocamento dos incorporadores para outros bairros que apresentam vantagens locacionais nas quais as estratégias de renovação podem ser repetidas.” (1996: 20-21)

Os ganhos alcançados por esta constante busca de inovação não se dão somente a partir da busca de novos espaços para o empreendimento, em razão do acirramento da concorrência, mas também pelo estabelecimento de um novo tipo de empreendimento - "condomínio fechado, apart-hotéis, flats, etc.- destinados a pessoas de poder aquisitivo superior ao daquelas que tradicionalmente habitam as zonas onde ele ocorre.” (Ribeiro, 1996: 115) Com isto, o autor tenta demonstrar a importância destes agentes na transformação do uso do espaço.

Ainda referindo-se aos padrões de incorporação, que vão exercer enorme influência no processo de produção espacial, Ribeiro (1996) trata, ainda, de um tipo de prática que se funda na expansão da fronteira urbana. Grandes áreas são compradas a baixo custo "e os empreendimentos são planejados de forma que os primeiros lançamentos vão sucessivamente revalorizando a área”. Para tal, faz-se necessária a criação de infra-estrutura, associação entre moradia, comércio e serviços, dentre outros elementos. A Barra da Tijuca é um exemplo ímpar neste processo, onde, a partir de lançamentos pioneiros e da criação de um pequeno núcleo de serviços e de comércio, verificou-se a expansão da área, chegando-se, hoje, como já mencionamos num momento anterior, a se veicular novos lançamentos em Jacarepaguá, ou mesmo no limite com Vargem Grande e Guaratiba como que situados na Barra.

No caso de expansão da Barra da Tijuca, tem-se evidenciado a tendência à oligopolização: os grandes incorporadores são responsáveis pelo controle de 70\% dos lançamentos entre 79/88 nesta área da cidade, onde, segundo Ribeiro (1997: 319-20), as incorporadoras produzem um menor número de unidades, contudo com preços mais elevados, destinando-as aos setores mais abastados.

Ribeiro, tratando do período em que se verificou o primeiro boom de crescimento da Barra (década de 70), apresenta alguns elementos importantes para se analisar as estratégias utilizadas pelo capital de incorporação, tendo em vista levar seus projetos a bom termo: 
Neste período, a Barra é palco de uma estratégia mercadológica que muito se assemelha àquela de criação de Copacabana. Um novo produto é colocado no mercado: o condomínio fechado que pretende reeditar um modo de vida campestre, associativo, protegido, entre iguais, etc. Trata-se de inventar uma nova diferenciação sócio-espacial que, produzindo uma obsolescência simbólica, fundamenta uma nova frente de geração de sobrelucros de localização, resolvendo-se assim as dificuldades de expansão criadas no período anterior. (1997: 314)

Ribeiro sugere, assim, que o objetivo estratégico fundamental do capital imobiliário era sua expansão, tendo como frente a consolidação da Barra, caracterizando "um novo momento de alteração do estado da divisão social do espaço da cidade como instrumento de criação de novas bases de apropriação de sobrelucros de localização”. (1997: 324)

Antes de procedermos à discussão em relação a outros agentes presentes no processo de produção do espaço urbano mais especificamente de uma área de autosegregação como se pretende a Barra da Tijuca, vale situar, ainda que brevemente, a relação estabelecida entre Estado e Capital Imobiliário, o que será retomado posteriormente, ao se discutir a gestão do espaço urbano.

Para tratar desta imbricação, vários paradigmas poderiam ser buscados, desde aqueles que defendem a soberania do mercado, até os que pensam o Estado como o grande regulador da sociedade, tendo sobre ela uma dimensão impositiva. Contudo, tendo em vista as especificidades da temática que vimos tratando- que, obviamente, não pode ser descolada, descontextualizada, extraída da dinâmica urbana nacional e mesmo global, optamos por acatar a proposição de Ribeiro e Azevedo:

A adoção do conceito de complexo financeiro-imobiliário em que o braço financeiro é altamente estruturado pelo Estado, tanto em nível de regulamentação (criação de linhas de crédito especiais, modus operandi, etc.), quanto de sua implantação, já que, historicamente, tem se dado prioritariamente através de agências para estatais (Caixa Econômica Federal, bancos estaduais, etc.). A "politização do mercado" - utilizando uma noção cunhada por Clauss Offe (1979)- antes de ser uma relação 
perversa entre Estado e Economia na sociedade brasileira, é uma das características nas modernas sociedades capitalistas. (1996:21)

O crescimento da Barra da Tijuca, por exemplo, só foi possível mediante esta articulação, onde o Estado investiu em infra-estrutura e linhas de crédito, de modo especial, permitindo ao investidor a rentabilidade do investimento. Este, por sua vez, ao buscar tal objetivo, pode assumir, basicamente, duas posturas: produzir em pequena escala, mas voltando-se para setores privilegiados (neste caso, o produto oferecido deve ser capaz de promover distinções materiais ou simbólicas em relação aos outros segmentos) ou interferir diretamente na transformação do uso do solo: de residencial em comercial, rural em urbano, popular em elitizado, etc.. (Ribeiro e Azevedo, 1996: 19). Assim fica visível que:

Estas estratégias implicam uma visceral imbricação entre este setor e as diversas esferas estatais, seja para garantir as condições especiais de financiamento que sustentem a lucratividade baseada no mais alto preço da moradia, seja para viabilizar, antecipar, controlar e direcionar as mudanças no uso do solo urbano, através de articulações e de informações privilegiadas. (Ribeiro e Azevedo, 1996: 19)

Ainda que a importância do Estado e dos representantes do capital (sobretudo imobiliário) sejam inegáveis na produção do espaço na Barra da Tijuca, faz-se mister a introdução do papel de inúmeros outros agentes neste processo.

\subsection{Os setores privilegiados (Classes Alta e Média-Alta):}

Enquanto, historicamente, a população pobre do Rio de Janeiro (e de outros grandes centros urbanos) foi empurrada, em razão da sua situação de destituição, para as regiões periféricas, desprovidas de infra-estrutura e serviços, caracterizando uma situação de segregação induzida (Souza, 1996: 54), a burguesia e os setores médios buscam áreas como a Barra da Tijuca- com seus condomínios exclusivos-, realçando um processo de auto-segregação. Conforme nos indica Souza:

Os condomínios exclusivos da Barra da Tijuca, no município do Rio de Janeiro, são atraentes para a burguesia e a classe média alta devi- 
do, em parte, a fatores como a presença de amenidades naturais e cênicas (praias, lagoas, vista dos maciços da Pedra Branca e Tijuca), status e "exclusividade". Além do mais, os condomínios proporcionam uma dose apreciável de conforto aos seus moradores, por oferecerem, dentro de seus muros, um comércio às vezes significativo (farmácia, padaria, etc.) e vários serviços, sem falar nas possibilidades de lazer e distração existentes em cada condomínio (piscina, sauna, quadras de esportes). (...) Há, porém, ouro fator, além da exclusividade", que torna os condomínios uma opção muito atraente para os setores privilegiados, e que, precisamente, desde o começo da década de 1980, em larga medida, vem respondendo pela popularidade que essa forma de morar passou a adquirir junto àqueles setores: o fator segurança. (1996:54-55):

\subsubsection{Um novo estilo de morar e de viver}

Em áreas como Barra foi vislumbrada, por parte das elites, a possibilidade de manutenção de um distanciamento em relação aos problemas urbanos, por vezes defendida como se significasse uma tentativa de busca de autonomia:

A auto-segregação baseada em condomínios, que parece representar uma busca de autonomia(...), o é em um sentido que violenta o pensamento autonomista clássico (...): ela não representa, nem de longe, a liberdade de fazer com os outros, o interesse pela cidade, mas sim a autonomia enquanto isolamento (escapismo hipócrita: os que têm condições de se auto-segregar estão articulados de mil maneiras, inclusive enquanto patrões nos marcos da exploração capitalista, aos destinos daqueles que eles desejam excluir de seu cotidiano, banir de sua paisagem). (1996: 260)

A relação dos moradores nos espaços auto-segregados é tão paradoxal ao ponto de, por exemplo, a compra do tão sonhado apartamento de frente para o mar não significar, objetivamente, a freqüência à praia, o que costuma ser justificado pelo medo do "contágio" com os não iguais- leia-se, pobres-, com os riscos que somente sua presença costuma suscitar (sic!); pela falta de tempo, pela possibilidade de acesso a opções de lazer outras, oferecidas tanto pelos próprios condomínios, quanto por 
clubes e mesmo pelos shoppings (igualmente seletivos- ainda que, como já constatamos, nestes esta pretensa assepsia não raras vezes seja desmanchada).

Parafraseando Chesneaux, os espaços auto-segregados são duplamente desfavoráveis ao amadurecimento de uma vida política coletiva.

Enquanto espaço construído, não é capaz de oferecer as referências inscritas no tempo, não se conhece onde reencontrar para se exprimir e agir conjuntamente. Enquanto coletividade humana, é mais um conglomerado instável que uma verdadeira comunidade construída progressivamente. As pessoas se entrecruzam e não se conhecem, refugiando-se no espaço-refúgio da habitação privada. Que sociedade nova pode surgir daí, que novas formas de vida política, que novos lugares de memória? (1996: 37)

Ancorados no medo, nestes espaços auto-segregados atribui-se toda uma ênfase ao controle, à vigilância. Se Foucault tivesse podido analisá-los, certamente repetiria as mesmas palavras que destinou à análise de contextos tão diferenciados- as instituições totais:

E para se exercer, esse poder deve adquirir o instrumento para uma vigilância permanente, exaustiva, onipresente, capaz de tornar tudo visível, mas com a condição de se tornar ela mesma invisível. Deve ser como um olhar sem rosto que transforme todo o corpo social em um campo de percepção.(...) E ao contrário dos métodos de escrita judiciária ou administrativa, o que é assim registrado são comportamentos, atitudes, virtualidades, suspeitas- uma tomada de contas permanente do comportamento dos indivíduos. (1991: 188)

A sofisticação do modelo de vigilância adotado pelos condomínios e shopping, vai desde à contratação de firmas de segurança, até à utilização de meios eletrônicos (câmeras de vídeo, walkie-talkies, etc.), sem falar na própria arquitetura (no caso dos shopping, principalmente)- que permite se ter uma visão, ainda que parcial, de todos os seus andares , o que potencializa o "olho do poder" e, tal qual no panopticon, acaba por 
inibir quaisquer tentativas de subversão da ordem.

A questão referente a mecanismos de controle/proteção não é algo novo na história da humanidade. Aristóteles, na sua "Política”, já falara sobre o papel das muralhas na proteção das cidades e controle contra sua invasão:

Ter a pretensão de não circundar a cidade de muralhas é criar um país fácil de ser invadido (...) nem se deve esquecer que uma cidade cercada de muralhas pode ou não servir-se delas, ao passo que, se absolutamente não as possui, a escolha é impossível. Se assim é, pois, deve-se não só construir muralhas à volta da cidade, mas ainda delas cuidar, a fim de que sirvam ao ornamento e à suntuosidade do lugar. (.s/d/88)

Podemos perceber, com isto, que tanto os shopping, quanto os condomínios, ao se utilizarem das mais variadas estratégias de vigilância/proteção não o fazem tão somente por razões operacionais, mas sobremaneira por razões políticas e ideológicas. Enquanto Aristóteles tratava da importância das muralhas na proteção da Pólis de invasões, pilhagens ou guerras, nos dias de hoje os segmentos/classes privilegiados criam toda sorte de mecanismos para protegerem-se de um inimigo que, historicamente, vem tendo sua imagem associada à violência, ao banditismo: os segmentos pobres ou, como se tem preferido dizer, os excluídos.

Neste sentido, consideramos necessário fazer uma reflexão sobre questões que, para além da dinâmica objetiva posta pelas relações estabelecidas na esfera da produção, repercutem na criação e divulgação de uma nova forma de morar e de viver, marcada pela "privatização da vida”, pela "busca da intimidade”, pela estilização e espetacularização do cotidiano, por relações de poder, ancoradas em elementos simbólicos, culturais e políticos.

Um dos elementos a ser colocado em pauta refere-se à tendência, iniciada no século passado e aprofundada neste, de “privatização da vida”, refletindo na criação de estratégias objetivas de confinamento, de recusa de contato com o que se considera hostil, com o inimigo. Isto porque a cidade, dada sua complexidade, transformou-se num “território sem leis”, mesmo congregando a possibilidade do encontro, da troca. 
Referindo-se ao mundo urbano, afirma Lefèbvre:

Para o poder, há mais de um século, qual a essência da cidade? Cheia de atividades suspeitas, ela fermenta delinqüências; é um centro de agitação.

Ao mesmo tempo que lugar de encontros, convergência das comunicações e informações, o urbano se torna aquilo que sempre foi: o lugar do desejo, desequilíbrio permanente, sede da dissolução das normalidades e coações, momento do lúdico e do imprevisível.” ( 1969: 76-77)

Sem sombra de dúvida, a "busca da Intimidade” tem a ver com o medo, a insegurança que a população citadina acaba por incorporar. Viver nas grandes metrópoles é, hoje, um exercício diário de enfrentamento do fantasma da violência que grassa em todos os lugares. Cada vez mais, segmentos populacionais destas megalópoles fechamse em espaços privativos, crendo, com isto, exorcizar estes “maus espíritos”. Assim, a sociabilidade fica comprometida; exacerbam-se sentimentos corporativos, atitudes segregatórias, abandona-se a fraternidade, a exemplo do que nos indica Sennet:

A fraternidade se tornou empatia para um grupo selecionado de pessoas, aliada à rejeição daqueles que não estão dentro do círculo local. Esta rejeição cria exigências por autonomia em relação ao mundo exterior, por ser deixado em paz por ele, mais do que exigências para que o próprio mundo se transforme. A fragmentação, a divisão interna, é a própria lógica dessa fraternidade, uma vez que as unidades de pessoas que realmente pertencem a ela vão se tornando cada vez menores. É uma versão de fraternidade que leva ao 'fratricídio'. (1989: 325).

O autor atribui este fato à própria lógica do capitalismo, cuja premissa fundamental é, justamente, o princípio da dissociação, da alienação. O Modo de Produção Capitalista não só supõe tal princípio nas relações de produção, quanto reforça-o, cotidianamente, nas mais diferentes instâncias da vida dos indivíduos.

$\mathrm{O}$ ato de circular (ou se trancafiar) em espaços privativos, objetivando, com isto, a defesa frente ao mundo exterior, marcado pela 
violência, pela hostilidade, não chega a interferir, positivamente, para a mudança do quadro de caos ou de guerra civil instaurada. Ao contrário de ser uma forma de combate aos males da sociedade capitalista, “ resulta numa espécie bizarra de retraimento despolitizado; o sistema permanece intacto; mas talvez consigamos fazer com que nosso torrão não seja afetado”. (Sennet, 1989: 360)

\subsection{Os segmentos populares:}

Malgrado todo este empreendimento objetivando evitar tal aproximação, constata-se que os segmentos pobres têm, outrossim, interferido, organizados ou não (opção esta que tende a ser mais verdadeira) na produção/ocupação do espaço da Barra da Tijuca. E isto, em certa medida, tem sido potencializado pelas necessidades postas pelos próprios moradores do bairro e/ou pelas facilidades de acesso à área, proporcionadas pela melhoria significativa de sua infra-estrutura urbana （e, inclusive, pela facilitação de sua ligação com outras áreas da cidade- um bom exemplo seria a construção da Linha Amarela). É como se, parafraseando Marx, pudéssemos sugerir que as armas forjadas pelos segmentos dominantes (aqui representados pelo próprio Estado, empreendedores imobiliários e grupos abastados) estivessem voltando-se contra eles próprios.

O crescimento do bairro, tanto em termos imobiliários, quanto em relação a outros serviços (sobretudo o comércio), passou a demandar toda uma gama de mão-deobra para sua sustentação. Os “emergentes” que lá se instalaram necessitaram recrutar empregadas, babás, jardineiros, pedreiros, etc.. As lojas (instaladas ou não nos shopping) transformaram-se em mercado de trabalho para jovens oriundos de outros bairros da Zona Oeste e Norte, sobremaneira. O grande equívoco, assim, daqueles que investiram na Barra foi supor que a população mais pobre manter-se-ía circunscrita aos locais que, “historicamente”, a ela foram reservados, a exemplo do que nos sugere Pinheiro:

A turbulência urbana levou o brasileiro afluente a acreditar na assepsia da exclusividade, que nasceu muito antes dos shopping. Suas pegadas estão no elevador de serviço para os empregados, na prisão especial para bacharéis, em farto repertório de preconceitos. Não há nada de errado com os shopping- a não ser quando contribuem para imaginar que não foram feitos também para a rapaziada do Morro dos Macacos. A louvada criatividade nacional já concebeu o futebol de quadra, entre quatro 
paredes. Mas delira com a possibilidade de inventar a sociedade de salão. (Veja, 09/10/96: 17)

Verifica-se, outrossim, uma crescente favelização do bairro, nos arredores das lagoas e outras áreas de risco lá existentes, algumas destas favelas surgidas a partir de alojamentos temporários para a força de trabalho empregada nas construções realizadas no primeiro período de expansão da Barra. Quando não situadas na própria Barra, podem ser constatadas em grande escala em Jacarepaguá, o que não deixa de ser preocupante, dada a proximidade em relação ao "bairro nobre”, o que, aos olhos dos moradores deste, pode significar uma constante ameaça. Podemos sugerir como exemplo o que vem ocorrendo com a favela de Rio das Pedras que, de 1992 para cá, (após parte da lagoa de Camorim ter sido aterrada, a partir de decisão do Governo Estadual, para assentar "sem-teto" ) vem tendo uma expansão assombrosa, já contando com cerca de 50.000 habitantes que já constróem em direção aos condomínios da Barra, soando aos moradores destes como uma ameaça.

Isto sem falar na outra “mancha” que existe na região: a Cidade de Deus, com todo seu histórico de segregação, tráfico e violência. As favelas surgem, segundo Lopes, “nas entrelinhas da ocupação seletiva da área.” (Apud Leitão, 1990: 173) Diferentes agentes envolvidos na produção do espaço do Bairro (Associações, empresários e autoridades municipais) chegam a atribuir este fato à natureza dos planos e legislações urbanísticas que orientam (ram) a ocupação da área, que não previam locais para construção de moradias populares.

\subsection{Os Movimentos Sociais, as “Campanhas” e a Mídia:}

Outros agentes, indubitavelmente, não podem ser deixados de lado, hoje, quando se fala da produção do espaço urbano.

Em relação aos movimentos sociais, a luta por direitos de cidadania, colocada por eles como pauta nas suas diferentes ações, implicou e vem implicando, também, numa luta pela produção e usufruto do espaço urbano. Se, antes, a população citadina ficava a mercê dos mandos e desmandos do Estado- por longo tempo tornado agente quase que exclusivo na produção / organização do espaço- via movimentos sociais a sociedade civil passa a propor e ou tomar as rédeas de práticas sociais neste sentido. 
Na Barra da Tijuca, a AMABARRA teve um papel decisivo, nos anos 80, na pressão junto ao Estado, com vistas ao alcance de melhoria das condições de infraestrutura do bairro. Na década de 80, por exemplo, a referida associação foi capaz de ampliar o próprio conceito de reivindicação à medida em que, “a partir de toda uma história de luta, os seus integrantes estavam conscientes de que o problema da Barra da Tijuca e, por extensão, do resto da Baixada de Jacarepaguá não se limitava a esta área, mas dizia respeito à própria forma como se encarava o equipamento sanitário nos órgãos competentes do Estado.” (Evangelista, 1989: 76).

Nos anos 90, contudo- e isto não é prerrogativa só da AMABARRA, mas dos movimentos de bairro em geral,- constata-se um enfraquecimento/ esfacelamento de ações de movimentos como este. Um dado exemplar neste sentido é a natureza da discussão que vem suscitando o problema referente à expansão da favela de Rio das Pedras, já mencionado anteriormente. Na década de 80, com certeza, tal problema já seria motivo suficiente para a organização de grupos ambientalistas e pressão junto ao governo para resolução dos impasses ecológicos criados. A AMABARRA, por sua vez, talvez já estivesse levantando a bandeira pró-saneamento e urbanização da região. Hoje, ao contrário, a grande mobilização que tem sido anunciada parte dos condomínios situados em áreas próximas e ameaçados pelo avanço indiscriminado da favela, deixando transparecer por parte dos moradores uma preocupação corporativista.

No momento atual, outros agentes entram em cena, cuja natureza é bastante distinta daquela detida pelos movimentos sociais urbanos, não possuindo um conteúdo político-reivindicativo em suas práticas aos moldes daquele detido pelas iniciativas dos anos 80. Seu modo de fazer política, de envolver "gregos e troianos" nas suas ações chegam a ser paradoxais. Contudo, sua importância tem sido inegável, dada a "eficiência” de suas ações, a resolubilidade de suas propostas.

Ora com práticas pontuais, ora com interesses corporativos, ora levantando a bandeira da solidariedade, o que é certo, contudo, é que a sociedade civil brasileiratalvez não com o potencial crítico e/ou transformador (ainda que questionáveis) que marcou os movimentos sociais surgidos nos anos 80- tem criado outras estratégias de mobilização/ ação. As chamadas “campanhas”, por exemplo, (re) surgem neste contexto, dispondo de uma flexibilidade organizativa e política maior que a dos movimentos sociais tradicionais, sem contudo negar a relevância dos partidos e do Estado. Propon- 
do-se, ao menos teoricamente, como a-classistas e a-partidárias, elas conseguem mobilizar os mais diferentes segmentos da sociedade civil e fazer pressão junto ao Estado. (Soares, 1996: 294-5)

O MOVIMENTO Viva Rio, dentro desta perspectiva, pode ser um exemplo de novo agente presente no processo de produção do espaço na Cidade do Rio de Janeiro. Sua atuação foi fundamental na época em que algumas famílias que residiam em áreas de risco nas proximidades da Barra perderam "tudo" o que tinham em razão das enchentes. Buscando parcerias com a iniciativa privada, com as Universidades e com o próprio Estado, sem falar na promoção de campanhas junto aos moradores privilegiados do bairro, conseguiu garantir que estas famílias reconstruíssem suas casas (obviamente numa área mais afastada). Para Soares,

O Viva Rio, o Green Peace ou a Campanha Contra a Fome não são necessários ou inevitáveis, mas terão êxito se nos convencerem de que são necessários enquanto atual-assim como o amor-para o poeta Vinícius de Moraes: “...não seja imortal, posto que é chama, mas que seja infinito enquanto dure." O fim de uma campanha é o fracasso de um movimento popular, mas um momento de reelaboração e metamorfose, em que novos formatos e novos agentes se afirmam, quando sabem adaptar-se aos novos ambientes sociais”. (1996: 299)

Dentre os agentes que interferem no processo de produção do espaço no mundo urbano mais especificamente, no local a que nos referimos-, é importante ressaltar o papel da mídia, que faz da imagem, do simbólico, elementos fundamentais de leitura do mundo urbano. Através dela, torna-se possível "ver a cidade”, que "significa perceber os seus fragmentos e decodificar os elementos constitutivos do espaço urbano”. (Egler, 1992: 70).

Assim pensada, a cidade, como um conjunto de símbolos dispersos, irá encontrar na documentação visual a linguagem mais completa para tratar da produção do conhecimento sobre os lugares e o os territórios da cidade, em que a imagem é o processo de representação de símbolos dispersos.

A imagem fotográfica, analógica ou digital, possibilita esse registro de forma mais próxima à natureza e percepção do espaço. Trata-se 
de um recorte: sobre o mesmo objeto é possível produzir diferentes imagens e, portanto, desencadeamentos analíticos distintos, bem como percepção e interpretação diferenciadas. No dizer de Ferrara (1991): “A utilização de veículos audio-visuais permite a criação e a recriação, dinamiza a capacidade associativa de reconhecer e operam linguagens- inventa novas cidades e novas linguagens. (1992: 70)

Esta capacidade detida, por exemplo, pelos meios de comunicação (a TV, especialmente) para criar imagens e, até mesmo, seguindo o caminho sugerido por Egler, "inventar novas cidades" é fundamental para se compreender a razão de sua força no jogo político contemporâneo-, bem como na produção do espaço urbano.

Os meios de comunicação tornaram-se para a população uma instância capaz de encurtar caminhos, seja na resolução de problemas individuais, seja no encaminhamento de problemas coletivos. "Cidade Alerta”, "Ratinho Livre”, "Globo Comunidade”, dentre outros, serviriam a tais objetivos. Por outro lado, ao contrário do que se postulara em outros momentos onde existir politicamente relacionava-se ao nível de engajamento partidário, sindical, etc.-, hoje é poder ser “coberto” pela mídia, “e o impacto político se mede conforme a audiência da mídia. (...) Na sociedade pulverizada, a comunicação assim engrandecida torna-se um importante agente político, um fundamento social”. (Cheneaux, 1995:26) Ainda segundo este autor, antes

O cidadão exigia contas, reivindicava sua parcela de responsabilidade no controle dos negócios públicos; mas ele se dilui diante do usuário cuidadoso que é "girado" pela máquina social, somente preocupado em conseguir realizar as suas necessidades habituais e que os serviços- como a eletricidade- sem os quais não pode passar, sejam garantidos. O cidadão se dilui diante do telespectador que acredita percorrer a terra inteira, enquanto mastiga distraidamente a comida padronizada de seu prato." (Chesneaux, 1996:150-1)

No caso específico da Barra, tem sido a mídia a principal difusora do estilo de vida que se pretende empreender no bairro. Não raras vezes, faz-se referência ao bairro em propagandas, em telenovelas e telejornais, abre-se "espaço" para que os ditos "emergentes” ou sociedade produtiva, como preferem ser chamados- possam se colocar, seja para exaltarem seu modo de vida, seja para divulgarem as campanhas que empreendem. 


\section{A fragmentação de tecido sócio-político-espacial:}

A Barra é, hoje, um bairro onde sua organização espacial apresenta, na contexto da cidade do Rio de Janeiro, uma forma sui generis, sobretudo quando percebemos a existência de "arranjos espaciais" que acabam por fragmentá-la, (re) produzindo contradições e reinventando paradoxos presentes na cidade que, algum dia, seus empreendedores e moradores pioneiros acreditavam poder deixar para trás.

Sua configuração demonstra a setorialização/ espacialização/ especialização de algumas áreas/atividades, fato este que, embora não sendo prerrogativa do bairro, (já que isto é bastante comum, sobretudo em cidades planejadas (como Brasília, Curitiba, etc.), assume nesta região algumas especificidades, dado sua "premissa de exclusividade".

Há, assim, áreas de moradia (os condomínios) que podem congregar um pequeno comércio em seu interior, bem como atividades de lazer; "centros de trabalho", como será o caso do Downtown (cuja construção está em vias de conclusão), objetivando atrair empresários moradores no bairro para transferência da sede de seus negócios para a região, isto permeado pelo discurso de otimizar o tempo, facilitar o acesso, aproximar trabalho/moradia; shoppings, transformados em miniaturas da cidade (vide modelo "Cidade Barra Shopping”), que abarcam um sem número de serviços (comércio, bancos, teatros, centros de saúde, etc.); hipermercados (que, para além dos gêneros alimentícios, produtos de higiene pessoal e limpeza do lar, possuem discoteca, livraria, jornaleiro, farmácia, lavanderia, floricultura, acessórios para carros e motos, etc.; centros de lazer (casas de espetáculos, áreas ecológicas, parque temático, etc).

Apesar de todas estas características, bem como à ordenação almejada para o bairro, há de se ressaltar, contudo, que a Barra nos parece um caso exemplar guardadas as devidas proporções e especificidades-, de desorganização do espaço urbano. Não devemos, com esta afirmação, confundir desorganização com desordem, o que não seria o caso. Tomemos, aqui, para o entendimento do significado do primeiro termo a discussão proposta por Chesneaux, que o entende como uma perda do sentido da vida na cidade:

A rua clássica era um lugar de socialização construído no tempo, definido pela pluralidade de suas funções de residência, de troca, de consumo, de relações humanas informais, de vida coletiva. Ela desaparece em proveito dos trevos para veículos pelos quais apenas se passa, e quase nunca a pé. 
Vias de acesso e desvios, estacionamentos subterrâneos ou galerias com lojas, túneis para pedestres ou espaços de lazer, o equipamento urbano visa apenas a acelerar a circulação, o movimento, a passagem.

A cidade se desarticula sob a pressão das prioridades de circulação, explode em zonas monofuncionais que são separadas umas das outras no espaço e no tempo, que têm apenas vida intermitente, e que estão quase mortas fora de suas praias de atividade funcional. Deve-se programar os deslocamentos para o centro comercial, a zona industrial, a região das escolas, o complexo hospitalar, o parque de jogos, o centro administrativo, em função da lógica particular a cada um deles. Pois cada um se inscreve num tempo limitador, como também num espaço limitador. (1996: 21).

Tanto os que moram, quanto os que tem negócios na Barra, parecem ter uma relação nestes moldes no e com o contexto do bairro. A impessoalidade, a individualidade dominam as ações dos diferentes sujeitos. Não se vê a rua como um espaço de sociabilidade ao contrário, ela é entendida como uma zona de risco, onde todos nós tornamo-nos sujeitos à hostilidade, à violência. As avenidas são, tão somente, espaços de circulação (de preferência, de carro e com os vidros fechados!). Os condomínios são locais de morar- e não de viver, pois isto implicaria numa relação menos impessoal, mais afetiva com o lugar, coisa que não acontece, já que sequer conhecemos aqueles que, teoricamente, seriam nossos "iguais" (oriundos de uma mesma classe, partilhando de valores semelhantes e, mesmo, medos comuns).

O espaço urbano da Barra encontra-se, assim, visivelmente fragmentado, concentrando "atividades e as pessoas incluídas /excluídas na nova ordem social e econômica”. (Ribeiro e Santos Junior (1993: 38). Ao lado dos shoppings e dos condomínios organizados segundo padrões internacionais, multiplicam-se as favelas, as ocupações irregulares. Isto só vem a comprovar que o destino de um lugar não pode, hoje, ser pensado fora do processo de globalização, que acaba por consolidar "nossa adesão ao modelo internacional de consumo urbano e suas conseqüências sobre a urbanização das cidades.” (Idem)

\section{O Processo de Gestão do Território na Barra da Tijuca.}

Pensar a gestão do território, hoje e, aqui, estaremos nos referindo, especificamente, a este processo no que se refere à Barra da Tijuca pressupõe compreender a interlocução e o nível de intervenção/ influência dos diferentes atores na definição dos rumos do espaço tratado. Isto porque, conforme nos sugere Correa, 
A gestão do território constitui uma faceta da gestão econômica, política e social, a ela estando subordinada, mas também condicionando-a . É a dimensão espacial do processo geral de gestão, confinando-se ao espaço sob controle de um estado, um grupo social ou de uma dada empresa.

Entendemos por gestão do território o conjunto de práticas que visa, no plano imediato, à criação e ao controle da organização espacial.(...) Em última instância, a gestão do território constitui poderoso meio que visa, através da organização espacial, a viabilizar a existência e a reprodução da sociedade.

Como qualquer outro fato social, a gestão do território possui uma historicidade que se traduz em agentes e práticas espaciais historicamente variáveis. Nas sociedades de classes a gestão do território implica a criação e a manutenção de diferenças espaciais através das quais as diferenças econômicas e sociais se realizam, são legitimadas e se reproduzem. Trata-se da gestão das diferenças espaciais. (1992: 115)

Falar em gestão, assim, significa falar em política, em poder, concebendo-os de maneira ampla, superando sua vinculação estreita e exclusiva ao Estado ou aos partidos. Isto porque, a exemplo do que nos sugere Becker:

Certamente o Estado não é a única unidade de poder, embora seja uma delas. E, certamente, o poder não é determinado pela configuração das terras e mares e pela geografia dos lugares e, sim, pelas motivações e decisões humanas e pelas relações sociais. (1988: 101).

O problema da produção e reprodução do espaço urbano, criação e implementação de infra-estrutura e redes de serviços, preservação do meio ambiente carecem do envolvimento de diferentes atores sociais. A forma como estes elementos vão ser definidos em termos de prioridades e administrados pelos diferentes agentes passa, necessariamente, por uma correlação de forças, onde cada um deles tenta defender suas “conveniências” e interesses, nem sempre afinados aos dos demais. Isto não significa, contudo, que, no processo de gestão do território não haja, entre agentes com interesses díspares, possibilidade de confluência de "conveniências", desde que não totalmente em desacordo com o que é hegemônico num dado contexto e momento histórico. 
Quando, por força do Neoliberalismo, o Estado se exime, cada vez mais, de determinadas responsabilidades e ações, demonstrando estar passando por um crescente ( e, irreversível? ) processo de fragmentação, cumpre-nos desvendar novas formas de gestão do espaço urbano que não o coloquem como centro das ações, mas apenas como mais um agente.

No caso do Rio de Janeiro, vimos assistindo, em consonância com o que se verifica na Federação, bem como no contexto global, uma tendência à privatização de determinados setores, como energia, telefonia, vias urbanas. No processo de produção do espaço, estas iniciativas acabam repercutindo em ampla escala, antagonizando segmentos que as defendem e outros que as rechaçam.

Entre os defensores, há os que afirmam que os modelos de gestão financeira das empresas privadas são mais eficientes que aqueles empreendidos pelo Estado, que, não raras vezes, acaba esbarrando na burocracia, aumentando o custo dos serviços ou da produção.

No caso específico da Barra, podemos dizer que sua ligação ao restante da cidade e ao mundo vem paulatinamente, sendo facilitada a partir do processo de privatização da TELERJ, que tem tentado atender a demandas reprimidas de muitos moradores por tantos anos.

Entre os opositores, não faltam críticas. A primeira delas seria a desigual distribuição de serviços quando estes são implementados pela iniciativa privada, desobedecendo a pressupostos de uma política urbana integral, pautando-se, ao contrário, na lógica do mercado. Assim, seus investimentos vão se concentrar em áreas rentáveis, ocupadas pela classe média ou alta ou- quando se trata de outras aos quais outros segmentos poderiam ter acesso- passa-se a cobrar ingressos caros, alto custo de estacionamento, valor abusivo do serviço prestado- exemplo disto são as rodovias privatizadas, parques e zoológicos, edifícios garagens. A linha Amarela, que liga a Barra a Zona Norte possui pedágio nos dois sentidos, com valores abusivos, restringindo o acesso da população mais pauperizada (que, ainda assim, possui o seu "fusquinha 66") às praias da região. O mesmo acontece na Região dos Lagos que, para ter acesso, o carioca acaba sendo onerado em pedágio duas vezes: uma na ponte e outra na BR que liga Niterói àquela localidade. 
Um outro efeito deste processo é analisado por Finquelievich:

Outro impacto importante es la desprotección de los habitantes urbanos frente al sector privado, debido a la ausencia de los instrumentos de control y regulación que el Estado y los organismos comunitarios podrían y deberíam ejercer sobre la prestación privada de los servicions públicos. Esta falta de repaldo se hace sentir epecialmente en las areas de fijación de tarifas, políticas de extensión territorial de los servicios, fijación y cumplimiento de normas de calidade en la prestación y defensa y representación orgánica de los derechos del ciudadano. (1993: 31)

Esta tendência amplamente difundida de se conceber a cidade como uma mercadoria, ao invés de um espaço de produção e consumo coletivo, de sociabilidade, de luta por direitos sociais, tem afastado ou inviabilizado a participação de muitos agentes sociais no seu processo de gestão (ou “co-gestão). Somente esta efetiva participação será capaz de possibilitar a implementação de programas e serviços consoantes com os efetivos interesses de todos os moradores da cidade, transformandoos em efetivos cidadãos. Isto porque,

La ausencia de control y regulación estatal y social favorece la ineficacia de le gestion de los servicios privatizados en lo que hace a los intereses de los usuarios, así como una provisión y distribución inadecuadas desde el punto de vista social y tecnológico. Es necesario entonces establecer objetivos definidos, plazos, regulaciones, standards, mecanismos de monitoreo y evaluación y sahciones para las empresas concessionárias. (Finquelievich, 1993: 32)

\section{Considerações Finais:}

A análise do processo de produção do espaço na Barra da Tijuca, além de propiciar a discussão sobre diferentes propostas de planificação e organização espacial da região, particularmente, e do contexto metropolitano, de uma forma geral, é , sem sombra de dúvida, extremamente elucidativa no que se refere às contradições e confrontos/ articulações entre os agentes que encaminham este processo. 
Temos consciência, contudo, dos limites da discussão que aqui empreendemos e isto, com certeza, tem a ver com a própria complexidade colocada pela temática que, para ser melhor problematizada, demandaria um investimento investigativo muito maior. Contudo, proceder a esta discussão para nós teve um significado especial, que foi o de poder melhor contextualizar nosso objeto de estudo ${ }^{7}$ e, de algum modo, por em xeque o pressuposto da auto-segregação.

Sem querer atribuir um tom conclusivo e irrefutável a esta afirmação- até porque, cremos poder melhor desenvolvê-la durante a tese de doutorado-, já constatamos alguns indícios de que, se algum dia ele existiu- em se tratando do caso específico da Barra da Tijuca-, hoje encontra-se num momento de crise.

Parece-nos complicada a idealização de um lugar imune às contradições do mundo urbano se ele aí se encontra circunscrito. Parece-nos ingenuidade supor que muralhas, câmeras, seguranças sejam capazes de constranger a violência que grassa na cidade. Parece-nos infantilidade acreditar que os segmentos pobres apesar de suas ações nem sempre introjetadas e vivenciadas como políticas possam restringir seus passos, no bairro, exclusivamente aos locais destinados ao trabalho, não vislumbrando possibilidades outras de circulação pelo espaço público (ainda que se queira fazê-lo privado), de vivência da alteridade e busca da identidade.

Recolocar /redimensionar a discussão em relação a processos de segregação faz-se, assim, fundamental, sobremaneira quando nos deparamos frente a um contexto que, num crescendo, vem tendendo a formas (talvez irreversíveis) de fragmentação/ desorganização do tecido sócio-espacial.

\section{Referências}

ABREU. Maurício. Evolução urbana do Rio de Janeiro. Rio de Janeiro, IPLANRIO/ ZAHAR, 1987.

ARISTÓTELES. A Política. Rio de Janeiro, EDIOURO, s/d.

BECKER, Bertha K. A Geografia e o resgate da Geopolítica. Revista Brasileira de

\footnotetext{
${ }^{7}$ Nosso projeto de doutoramento intitula-se: Shopping center- o afrouxamento da assepsia e o lugar da pobreza na cidade miniaturizada.
} 
Geografia, 50, nº especial, t.2, 99-125, 1988.

BOLAFFI, Gabriel. Habitação e urbanismo: o problema e o falso problema. In: MARICATO, Ermínia. A produção capitalista da casa (e da cidade). São Paulo, Alfa-Omega, 1982. P. 37-70.

CAVALLIERI, Paulo Fernando e BEZERRA, Márcia. O solo criado e o Plano Diretor do Rio de Janeiro. In Ribeiro, L. C. de Q. e Azevedo, Sérgio de. (org.) A crise da moradia nas grandes cidades: da questão da habitação à reforma urbana. Rio de Janeiro, UFRJ, 1996.

CHESNEAUX, Jean. Modernidade-mundo. (Trad.João da Cruz). Petrópolis, Vozes, 1996.

CORREA, Roberto Lobato. Corporação, práticas espaciais e gestão do território. Revista Geográfica Brasileira, Rio de Janeiro, 54(3), julho, setembro de 1992. 115-121.

EVANGELISTA, Hélio de Araújo. Uma abordagem geográfica à reivindicação por equipamento sanitário. Rio de Janeiro, UFRJ, 1989. Dissertação de Mestrado.

EGLER, Tamara Tania Cohen. A imagem do Rio de Janeiro na televisão. Cadernos IPPUR/UFRJ, ano VI, nº 1, dezembro de 1992.

A gestão do lugar e da cidade. Cadernos IPPUR/UFRJ, ano VIII, ${ }^{0} 1$, abril de 1994.

FINQUELIEVICH, Susana. Articulaciones entre el sector publico y el privado en la produccion y gestion del espacio urbano, un matrimonio de conveniencia? Cadernos IPPUR/UFRJ, ano VII, nº 3, dezembro de 1993.

FOUCALT, Michel. Microfísica do Poder. Rio de Janeiro, Graal, 1979.

. Vigiar e Punir. Petrópolis, Vozes, 1975.

GUIMARÃES, Gonçalo. Por uma cidade para todos: o Plano Diretor do município de Angra dos Reis. Rio de Janeiro, Forense, 1997.

LEFÈBVRE, Henri. O Direito à Cidade. São Paulo, Ed. Documentos, 1969.

LEITÃO, Gerônimo Emílio Almeida. O Plano Piloto da Barra da Tijuca e Baixada de Jacarepaguá- 1970/1988- um estudo das relações existentes entre o Estado e o Capital Imobiliário no processo de produção do espaço urbano. Rio de Janeiro, UFRJ, 1990. Dissertação de Mestrado. 
NAVET, Véronique. Formes et stratégies résidentielles des classes aisées au Brésil. Etude dún quartier de Rio de Janeiro: La Barra da Tijuca. Universite Paris V III. Institut Français d’Urbanisme. 1989, Tese de Doutorado.

PINHEIRO, Flavio. Sociedade de salão. Revista Veja, 09 de 0utubro de 1996. 17.

PREFEITURA DA CIDADE DO RIO DE JANEIRO. Decreto 3.046/ 81.

PREFEITURA DA CIDADE DO RIO DE JANEIRO. Plano Diretor Decenal da Cidade do Rio de Janeiro. Rio de Janeiro, 1993.

RIBEIRO, Luiz Cesar de Queiroz. Incorporação imobiliária: características, dinâmica e impasses. In Ribeiro, L. C. de Q. e Azevedo, Sérgio de. (org.) A crise da moradia nas grandes cidades: da questão da habitação à reforma urbana. Rio de Janeiro, UFRJ, 1996.

RIBEIRO, Luiz Cesar de Queiroz. Dos cortiços aos condomínios fechados - as formas de produção da moradia na Cidade do Rio de Janeiro. Rio de Janeiro, Civilização Brasileira: IPPUR, UFRJ: FASE, 1997.

RIBEIRO. Luiz Cesar de Queiroz e AZEVEDO, Sérgio de. A produção da moradia nas grandes cidades: dinâmica e impasses. In Ribeiro, L. C. de Q. e Azevedo, Sérgio de. (org.) A crise da moradia nas grandes cidades: da questão da habitação à reforma urbana. Rio de Janeiro, UFRJ, 1996.

RIBEIRO, Luiz Cesar Queiroz e SANTOS JÚNIOR, Orlando Alves dos. Das desigualdades à exclusão social, da segregação à fragmentação: os desafios da reforma urbana. Cadernos do IPPUR, ano VII, nº ${ }^{\circ}$, junho de 1993.

SENNET,Richard. O declínio do homem público- as tiranias da intimidade. (Trad. Lygia A, Watanabe). São Paulo, Companhia das Letras, 1998.

SINGER, Paul. O uso do solo urbano na economia capitalista. In: MARICATO, Ermínia. A produção capitalista da casa ( e da cidade). São Paulo, Alfa-Omega, 1982. P. 21-36.

SOARES, Luiz Eduardo. O herói serial e a sensibilidade pragmática: alguns comentários sobre a violência e a nova sociedade civil, no Rio de Janeiro. In Soares, Luiz Eduardo e colaboradores. Violência e política no Rio de Janeiro. Rio de Janeiro, Relume Dumará:ISER, 1996.

Souza, Marcelo J. Urbanizção e desenvolvimento no Brasil Atual. São Paulo, Ática, 1996. Souza, Marcelo J. Exclusão social, fragmentação do tecido sociopolítico-espacial da cidade e "ingovernabilidade urbana" - ensaio a propósito do desafio de um "desenvolvimento sustentável” nas cidades brasileiras. In: SILVA, José Borzacchiello da et alii. A cidade e o urbano - temas para debates. Fortaleza, EUFC, 1997. P. 247-264. 